\title{
Regional climate model data used within the SWURVE project 1: projected changes in seasonal patterns and estimation of PET
}

\author{
M. Ekström ${ }^{1}$, P.D. Jones ${ }^{1}$, H.J. Fowler ${ }^{2}$, G. Lenderink ${ }^{3}$, T.A. Buishand ${ }^{3}$ and D. Conway ${ }^{4}$ \\ ${ }^{1}$ Climatic Research Unit, School of Environmental Sciences, University of East Anglia, Norwich, UK \\ ${ }^{2}$ Water Resource Systems Research Laboratory, School of Civil Engineering and Geosciences, University of Newcastle, Newcastle upon Tyne, UK \\ ${ }^{3}$ KNMI (Royal Netherlands Meteorological Institute), De Bilt, The Netherlands \\ ${ }^{4}$ School of Development Studies, University of East Anglia, Norwich, UK
}

Email for corresponding author: M.Ekstrom@uea.ac.uk

\begin{abstract}
Climate data for studies within the SWURVE (Sustainable Water: Uncertainty, Risk and Vulnerability in Europe) project, assessing the risk posed by future climatic change to various hydrological and hydraulic systems were obtained from the regional climate model HadRM3H, developed at the Hadley Centre of the UK Met Office. This paper gives some background to HadRM3H; it also presents anomaly maps of the projected future changes in European temperature, rainfall and potential evapotranspiration (PET, estimated using a variant of the Penman formula). The future simulations of temperature and rainfall, following the SRES A2 emissions scenario, suggest that most of Europe will experience warming in all seasons, with heavier precipitation in winter in much of western Europe (except for central and northern parts of the Scandinavian mountains) and drier summers in most parts of western and central Europe (except for the north-west and the eastern part of the Baltic Sea). Particularly large temperature anomalies $\left(>6^{\circ} \mathrm{C}\right)$ are projected for north-east Europe in winter and for southern Europe, Asia Minor and parts of Russia in summer. The projected PET displayed very large increases in summer for a region extending from southern France to Russia. The unrealistically large values could be the result of an enhanced hydrological cycle in HadRM3H, affecting several of the input parameters to the PET calculation. To avoid problems with hydrological modelling schemes, PET was re-calculated, using empirical relationships derived from observational values of temperature and PET.
\end{abstract}

Keywords: HadRM3H, temperature, rainfall, PET, Europe

\section{Introduction}

The most important tools in the study of climate variability and possible future climate change are Coupled AtmosphereOcean General Circulation Models (AOGCMs). These models are state-of-the-art numerical integrations that represent subsystems of the Earth's climate; they simulate, reliably, the most important large-scale features of the present global climate, but show larger differences in simulated climate at finer spatial resolutions, i.e. features with space scales smaller than a few model grid boxes (Grotch and MacCracken, 1991; Räisänen, 2000).

There are several reasons for the reduced skill of AOGCMs at the regional or local scale. Firstly, the relatively coarse spatial resolution of the models provides an inadequate description of the structure of the Earth's surface; secondly, the hydrodynamics of the atmosphere are nonlinear and, because of numerical truncation in the models, the smallest scales are not resolved; thirdly, sub-grid scale processes in the models, e.g. cloud formation, rainfall, infiltration, evaporation and runoff, are all parameterised, which implies additional uncertainties in the AOGCM simulations (Zorita and von Storch, 1999).

For studies of the impact of climate change focused on water management, such as those conducted within the framework of the SWURVE project (Sustainable Water: Uncertainty, Risk and Vulnerability in Europe), a regional or local scale is essential. The regional detail necessary for hydrological and hydrodynamic studies can be derived from the coarse-scale outputs of global models by simple interpolation, statistical downscaling or high-resolution 
dynamical modelling, i.e. the use of regional climate models (RCMs) embedded within the global scale AOGCMs. In SWURVE, simulated regional climate data for each of the case study regions were obtained from the UK Hadley Centre RCM, HadRM3H (Jones et al., 2001b). HadRM3H is forced by boundary conditions from a coarser resolution global model and provides higher spatial resolution $\left(0.44^{\circ}\right.$ latitude and $0.44^{\circ}$ longitude) of local topography and more realistic simulations of fine-scale weather features for the European area.

Despite their higher spatial resolution, the RCM data are still associated with uncertainty. Although the largest contribution is generally considered to be inherited from the driving AOGCM (Jenkins and Lowe, 2003), the RCM itself is a source of uncertainty, partly due to the limitations in correctly representing sub-grid processes (Hulme et al., 2002). The main sources of uncertainty have been discussed extensively, as has the influence of uncertainty on model outcomes in general (Wigley and Raper, 2001; Giorgi and Mearns, 2002) and on hydrological applications in particular (Jones, 2000a, b; Anderson et al., 2001; Allen and Ingram, 2002).

In this two-part paper, the general seasonal characteristics of HadRM3H data have been examined for two time periods, 1960-1990, representing the present-day climate and 20702100 , representing a future climate influenced by predicted increases in anthropogenic forcings. Three variables, essential to hydrological modelling studies, are discussed: daily surface $(1.5 \mathrm{~m})$ temperature, daily rainfall totals $(\mathrm{mm})$ and potential evapotranspiration (PET). While temperature and rainfall are direct outputs from the HadRM3H, the PET is estimated using the FAO (Food and Agricultural Organization) Penman-Monteith method (Allen et al., 1994). The RCM gives actual evaporation (AE) rather than values of PET, which are required by the hydrological models, so PET must be calculated from the model data available. For the hydrological modelling applications in SWURVE, the FAO PET was determined but alternative, less datademanding, methods for deriving PET were explored for two of the SWURVE case study areas (Kilsby, 2007). For each of the five European case study regions within SWURVE, uncertainty in the HadRM3H data has been addressed (Ekström et al., 2007)

\section{Overview of Hadley Centre's regional modelling scheme}

The climate simulations from the Hadley Centre models are realisations of a set of scenarios, which can be thought of as coherent, internally consistent and plausible representations of possible future states of the world (Hulme et al., 2002).
The projections of future changes in the climate are based on estimates of future emissions of greenhouse gases and other pollutants, as well as other factors that may influence a future climate. Descriptions of how these atmospheric constituents may change in the future are provided in the Special Report on Emissions Scenarios (SRES) (IPCC, 2000) of the Intergovernmental Panel on Climate Change (IPCC). The report describes a set of possible future worlds and provides a framework within which climate change scenarios can be developed.

Four climate change scenarios were developed for the UK by the UK Climate Impacts Programme (UKCIP) (Hulme et al., 2002). The scenarios represent a climate forced by four different levels of emissions: low, medium-low, medium-high and high. The four UKCIP02 scenarios span the IPCC SRES emissions range (i.e. B1-A1F1) and are described as being plausible representations of future climate but with no probabilities assigned to them.

Physical realisations of the medium-high and the mediumlow UKCIP02 scenarios were generated for a European window by the Hadley Centre for Climate Prediction and Research at the UK Met Office, using a regional modelling system that comprises three climate models. The different resolution of the models produces a flexible system that removes some of the large regional circulation errors that generally accompany global coupled models.

The underlying AOGCM, HadCM3 (Gordon et al., 2000), was developed from the earlier coupled model HadCM2 (Johns et al., 1997). Information is exchanged between the ocean and the atmosphere components once a day, with heat and water fluxes being conserved exactly (Johns et al., 2003). The atmospheric component of the model (HadAM3) has 19 levels with a spatial resolution of $2.5^{\circ}$ latitude by $3.75^{\circ}$ longitude (Pope et al., 2000). Compared to HadCM2, HadCM3 includes a new radiation scheme, a new land surface scheme (Cox et al., 1999) and improved representations of penetrative convection, large-scale precipitation and cloud schemes (Johns et al., 2003). In addition to the general improvements, the atmospheric component of HadCM3 (HadAM3) also includes a sulphur cycle, which enables it to model transport, chemistry and physical removal processes of anthropogenic sulphate aerosols (Johns et al., 2003). The ocean component of HadCM3 has 20 levels and a higher resolution ( $1.25^{\circ}$ latitude by $1.25^{\circ}$ longitude) than the atmospheric component, which enables the model to capture important features in the current structure (Wood et al., 1999; Johns et al., 2003). HadCM3 was initialised, without spin-up, from a Levitus-observed (Levitus and Boyer, 1994; Levitus et al., 1995) ocean state at rest with a suitable atmospheric and sea-ice state (Johns et al., 2003). A control integration with fixed forcing 
provided the climate conditions for the late $19^{\text {th }}$ century. Subsequently, experiments with time-varying anthropogenic forcings, including the new IPCC SRES scenarios, were performed (Johns et al., 2003).

The regional detail of the modelling scheme was provided by two other models, HadAM3H and HadRM3H. The first is a global-scale higher resolution $\left(1.25^{\circ}\right.$ latitude by $1.875^{\circ}$ longitude) version of HadCM3's atmospheric component HadAM3 with some of its physical parameterisations changed. It provided a more accurate representation of the atmospheric response to global sea-surface temperature and sea-ice changes, as simulated by HadCM3 (Jones et al., 2001b). The second model is a regional climate model, which provided fine-scale spatial detail $\left(0.44^{\circ}\right.$ latitude by $0.44^{\circ}$ longitude) for an extensive European window (Hulme et al., 2002). This design improved simulation of the strength and position of the North Atlantic storm track and gave a more realistic representation of clouds and atmospheric humidity, which improve the radiation and precipitation schemes (Jones et al., 2001b).

Due to the large computing costs associated with the regional modelling scheme, the HadAM3H/HadRM3H combination was run for only two time windows: a control period (1960-1990) and a future perturbed period (20702100). During the control period HadAM3H was driven with observations of sea-surface temperatures and sea-ice for that period, whilst during the future integration, HadAM3H was driven by changes in SST and sea-ice as simulated by HadCM3, which were added to the observations (Hulme et al., 2002). Oceanic observations were used instead of modelled data because of the relatively poor control climate in HadCM3 (Räisänen et al., 2004).

Three realisations were run for the medium-high scenario (A2 in the SRES) and one for the medium-low scenario (B2 in the SRES). Each of the three A2 simulations had identical experimental design, the same historical changes and the same future changes in greenhouse gases and aerosols but were initiated from three different points in the control period and were based on different HadCM3 simulations. This procedure creates substantial year-to-year and decade-to-decade variability but has little effect on the long-term change (Hulme et al., 2002).

In this paper, the figures illustrating the control period and the relative difference of the perturbed period are based on only one ensemble member of HadAM3H, A2a. Because the long-term means of the ensemble members are similar, little difference from the other ensemble members is to be expected. Furthermore, the RCMs, which were used to assess uncertainty in Ekström et al., (2007), all used the A2a run of HadAM3H to represent the A2 scenario. The HadRM3H data were made available via the Climate
Impacts LINK project (Viner and Hulme, 1997) website (http://www.cru.uea.ac.uk/link/) at the Climatic Research Unit (CRU) of the University of East Anglia.

\section{Estimation of potential evapotranspiration}

Whilst daily temperature $\left[{ }^{\circ} \mathrm{C}\right]$ and rainfall $\left[\mathrm{mm} \mathrm{day}^{-1}\right]$ are direct outputs from $\mathrm{HadRM} 3 \mathrm{H}$, potential evapotranspiration (PET) estimates were calculated for the entire HadRM3H domain using a variant of the Penman-Monteith method; the grass reference evapotranspiration (Eqn. 1), developed by the Food and Agricultural Organization (FAO) (Allen et al., 1994); this defines PET as the potential evapotranspiration from a clipped grass-surface $0.12 \mathrm{~m}$ in height with a bulk surface resistance of $70 \mathrm{~s} \mathrm{~m}^{-1}$ and an assumed surface albedo of 0.23 . The meteorological variables are assumed to be measured at a height of $2 \mathrm{~m}$, which is the approximate height of most HadRM3H variables $(1.5 \mathrm{~m})$, apart from the wind $(10 \mathrm{~m})$. To overcome the height difference for the wind variable, a conversion factor, based on the logarithmic wind profile, was used to reduce the HadRM3H $10 \mathrm{~m}$ wind to the required $2 \mathrm{~m}$ height wind (see Allen et al., 1994). The FAO PET was estimated using the following formula:

$$
P E T=\frac{0.408 \Delta\left(R_{n}-G\right)+\gamma \frac{900}{T+273.16} U_{2}\left(e_{a}-e_{d}\right)}{\Delta+\gamma\left(1+0.34 U_{2}\right)},
$$

where:

\begin{tabular}{|c|c|c|}
\hline PET & : & $\begin{array}{l}\text { grass reference evapotranspiration } \\
{\left[\mathrm{mm} \mathrm{day}^{-1}\right]}\end{array}$ \\
\hline$R_{n}$ & : & $\begin{array}{l}\text { net radiation at crop surface } \\
{\left[\mathrm{MJ} \mathrm{m}^{-2} \text { day }^{-1}\right]}\end{array}$ \\
\hline G & : & $\begin{array}{l}\text { soil heat flux }\left[\mathrm{MJ} \mathrm{m}^{-2} \text { day }^{-1}\right] \text {, here } \\
\text { assumed to be } 0 .\end{array}$ \\
\hline$T$ & . & mean temperature at $2 \mathrm{~m}$ height $\left[{ }^{\circ} \mathrm{C}\right]$ \\
\hline$U_{2}$ & : & $\begin{array}{l}\text { wind speed measured at } 2 \mathrm{~m} \text { height } \\
{\left[\mathrm{m} \mathrm{s}^{-1}\right]}\end{array}$ \\
\hline$\left(e_{a}-e_{d}\right)$ & : & $\begin{array}{l}\text { vapour pressure deficit for } \\
\text { measurement at } 2 \mathrm{~m} \text { height }[\mathrm{kPa}]\end{array}$ \\
\hline$\Delta$ & . & $\begin{array}{l}\text { slope of the vapour pressure curve } \\
{\left[\mathrm{kPa}^{\circ} \mathrm{C}^{-1}\right]}\end{array}$ \\
\hline$\gamma$ & & psychrometric constant $\left[\mathrm{kPa}^{\circ} \mathrm{C}^{-1}\right]$ \\
\hline 900 & : & $\begin{array}{l}\text { coefficient for the reference crop } \\
{\left[\mathrm{kJ}^{-1} \mathrm{~kg} \mathrm{~K} \text { day }\right.}\end{array}$ \\
\hline 0.34 & : & $\begin{array}{l}\text { wind coefficient for the reference crop } \\
{\left[\mathrm{s} \mathrm{m}^{-1}\right] \text {, Allen et al. (1994) }}\end{array}$ \\
\hline
\end{tabular}

Wind speed and temperature are direct outputs from 
HadRM3H. In addition, net radiation, vapour pressure deficit and the slope of the vapour pressure curve were calculated using HadRM3H data. More specifically: total cloud, as estimated from long wave radiation from $\operatorname{HadRM} 3 \mathrm{H}$, was used to calculate the relative sunshine fraction, i.e. bright sunshine hours per day divided by total day length (Allen et al., 1994); surface temperature (mean, minimum and maximum) and relative humidity were used to calculate the vapour pressure deficit and the slope of the vapour pressure/ temperature curve.

\section{Seasonal anomaly fields}

The entire HadRM3H integration domain covers an extensive European window with $111 \times 106$ grid cells in the latitude/longitude directions (the wind fields are on a staggered grid of $110 \times 106$ cells). This area includes an 8 -grid cell boundary zone (necessary for the nesting within HadAM3H), which has been removed from the maps in this paper.

Seasonal maps of the control period are provided to aid the interpretation of the later anomaly fields (Figs. 1, 3, and 5 for temperature, rainfall and PET respectively). The projected changes in temperature, rainfall and FAO PET are shown as seasonal anomalies. The anomalies are created by subtracting the 30 -year grid cell averages of the control simulation from the future simulation (Figs. 2, 4, and 6 for temperature, rainfall and PET respectively). The seasons were defined as: winter (December to February), spring (March to May), summer (June to August) and autumn (September to November).

The most widespread anomalies in temperature occur in summer (Fig. 2c). Average temperature is projected to increase by more than $6{ }^{\circ} \mathrm{C}$ for large parts of central/northern Europe, southern Europe and northern Africa. Somewhat larger increases $\left(\sim 7-8^{\circ} \mathrm{C}\right)$ are projected for central-southern France and parts of Russia $\left(\sim 60^{\circ} \mathrm{N}\right.$ and $\left.45^{\circ} \mathrm{E}\right)$. More moderate increases $\left(\sim 5-6^{\circ} \mathrm{C}\right)$ are projected for most of central Europe with smaller increases $\left(\sim 2-5^{\circ} \mathrm{C}\right)$ over the British Isles and Fennoscandia. The winter season also shows widespread temperature anomalies (Fig. 2a), with a west to east gradient of increasing anomalies from $\sim 3^{\circ} \mathrm{C}$ over the British Isles to $\sim 7^{\circ} \mathrm{C}$ over central Russia. The large increase in the north-east corner (Russia) is likely to result from large changes in snow and ice conditions, which affect the radiative balance. In spring (Fig. 2b), anomalies typically range from 3 to $5^{\circ} \mathrm{C}$, with even larger values in northern Russia and northern Finland; except for Iberia and large parts of Morocco and Algeria, increases tend to be smaller towards the west. During autumn, the largest projected increases are in the northern regions of Europe and also in Algeria $\left(\sim 5^{\circ} \mathrm{C}\right)$, while the rest of Europe shows somewhat smaller increases (Fig. 2d). In short, temperatures increase during all seasons and particularly in southern and central
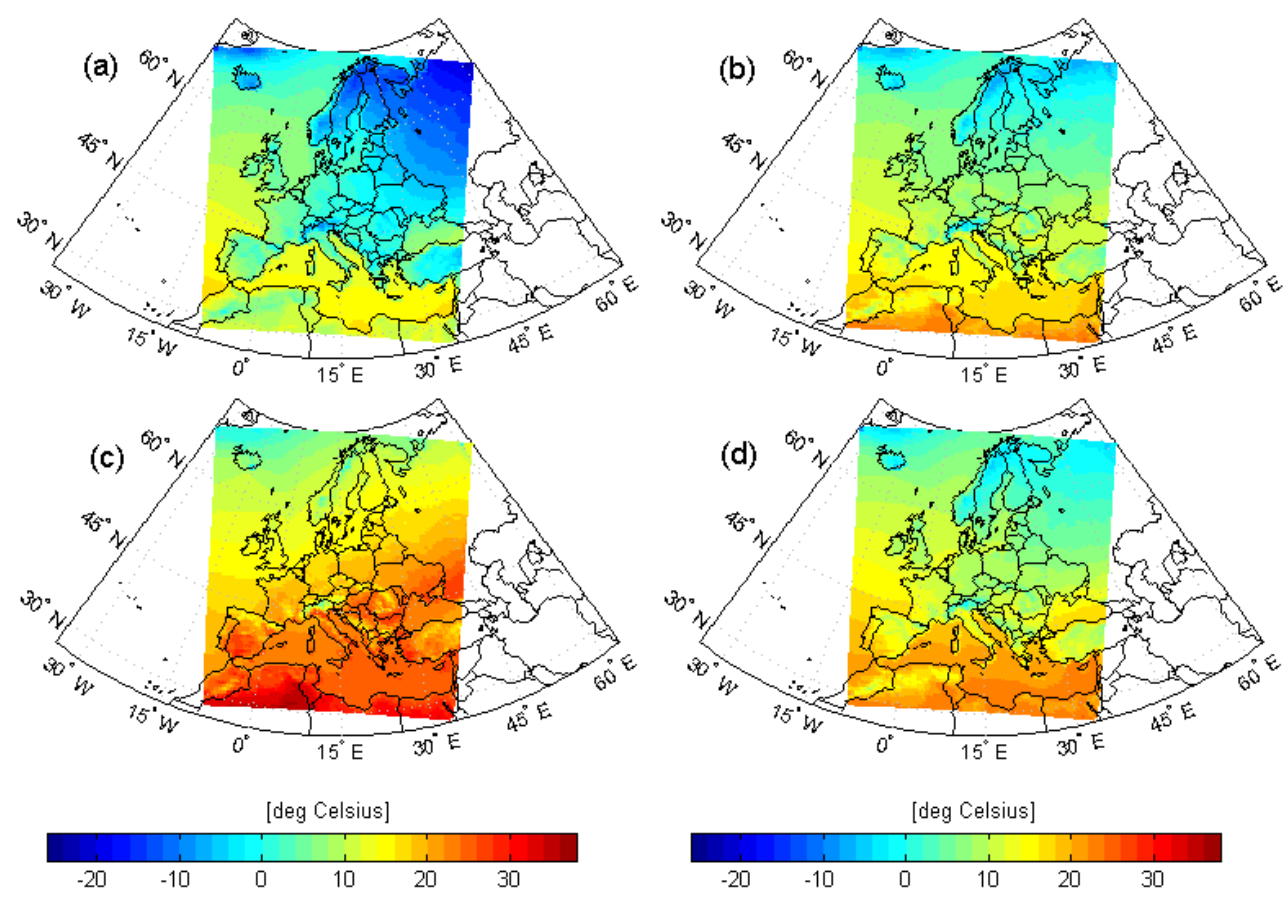

Fig. 1. Seasonal averages of temperature $\left[{ }^{\circ} \mathrm{C}\right.$ at $\left.1.5 \mathrm{~m}\right]$ for the entire HadRM3H integration domain for the period $1960-1990 ;$ (a) winter (December to February), (b) spring (March to May), (c) summer (June to August) and (d) autumn (September to November). 

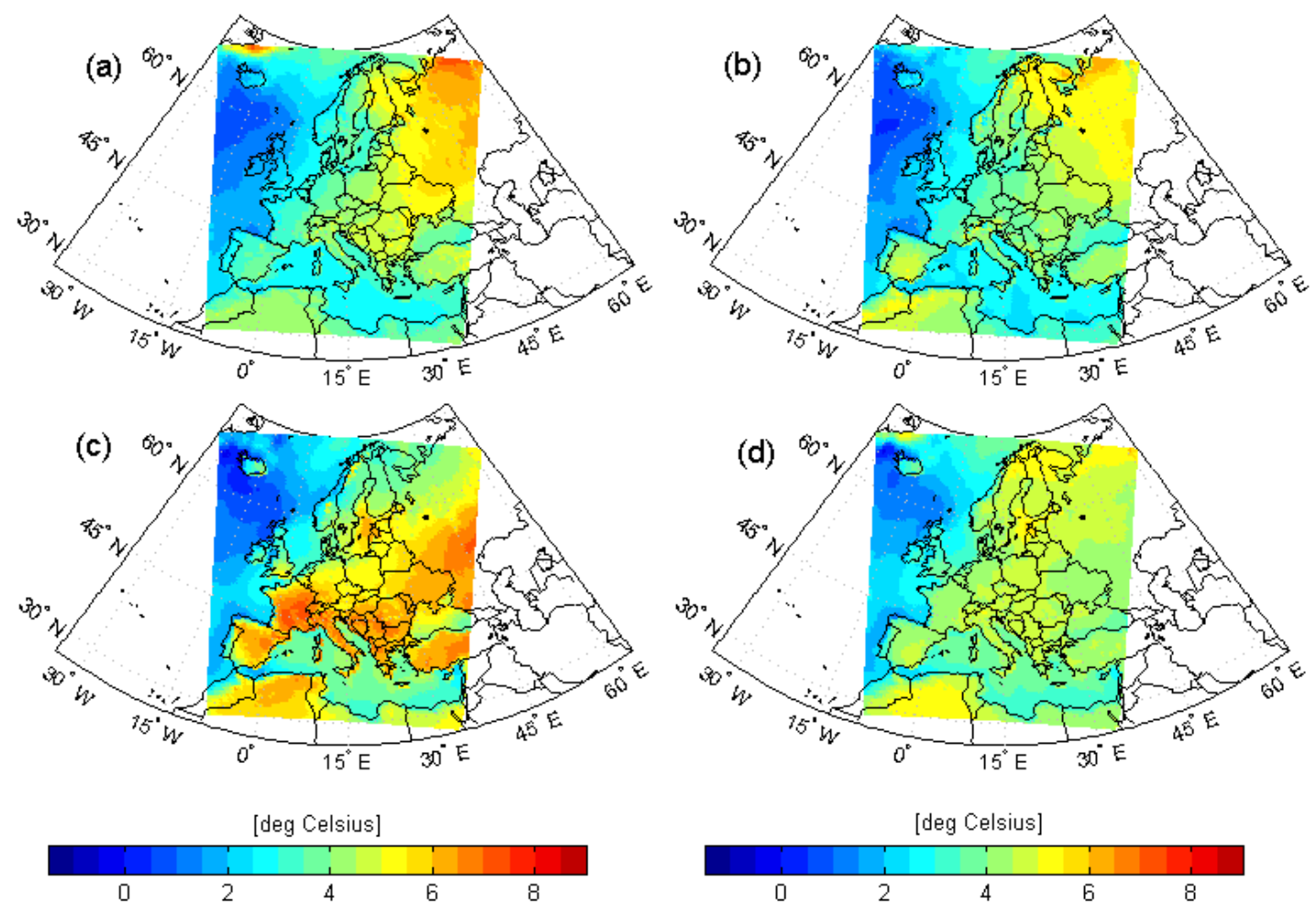

Fig. 2. Seasonal temperature anomalies $\left[{ }^{\circ} \mathrm{C}\right.$ at $\left.1.5 \mathrm{~m}\right]$ for the entire HadRM3H integration domain (difference between the periods 2070-2100 and 1960-1990): (a) winter (December to February), (b) spring (March to May), (c) summer (June to August) and (d) autumn (September to November).
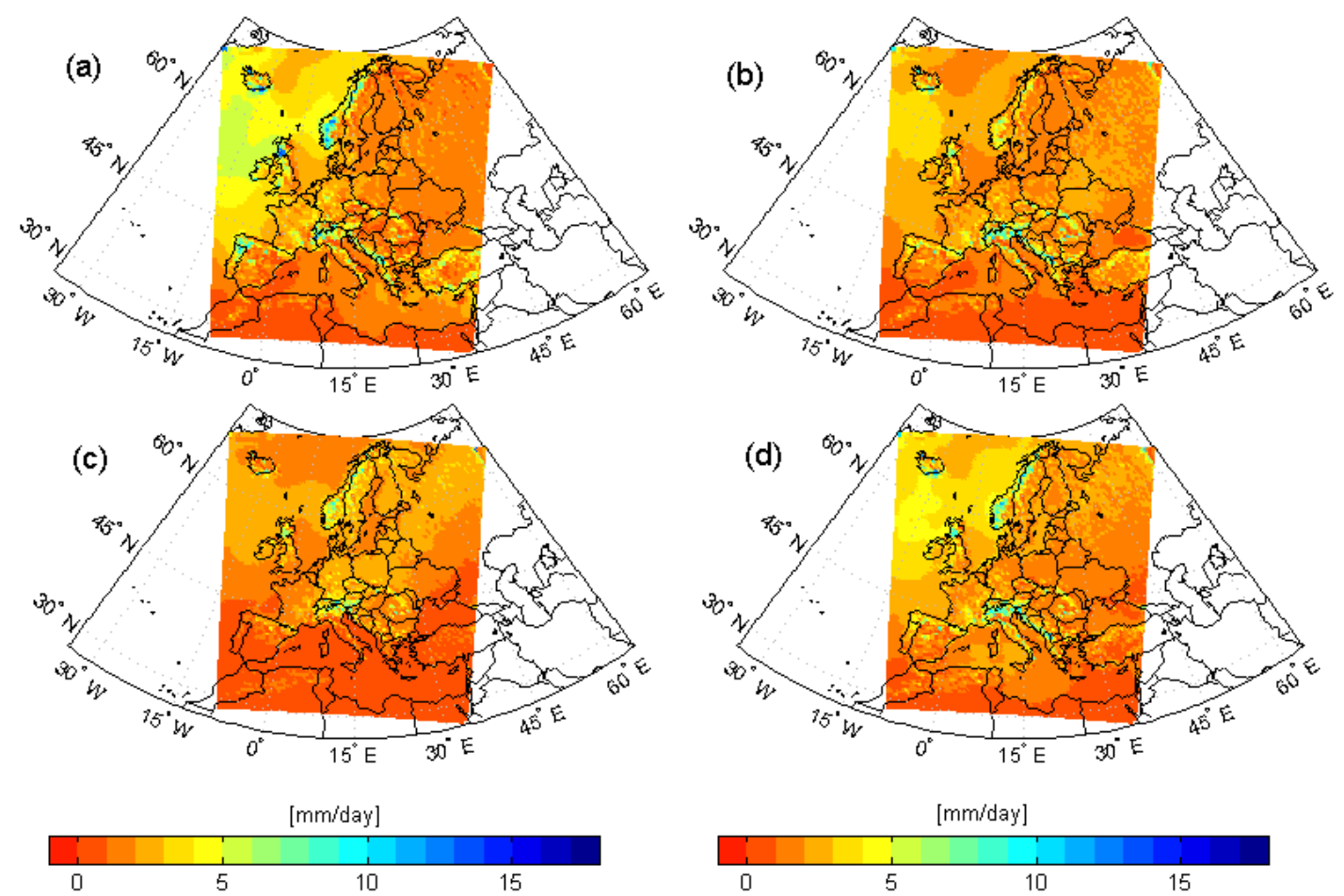

Fig. 3. Seasonal averages of rainfall [mm day $\left.{ }^{-1}\right]$ for the entire HadRM3H integration domain for the period 1960-1990; (a) winter (December to February), (b) spring (March to May), (c) summer (June to August) and (d) autumn (September to November). 

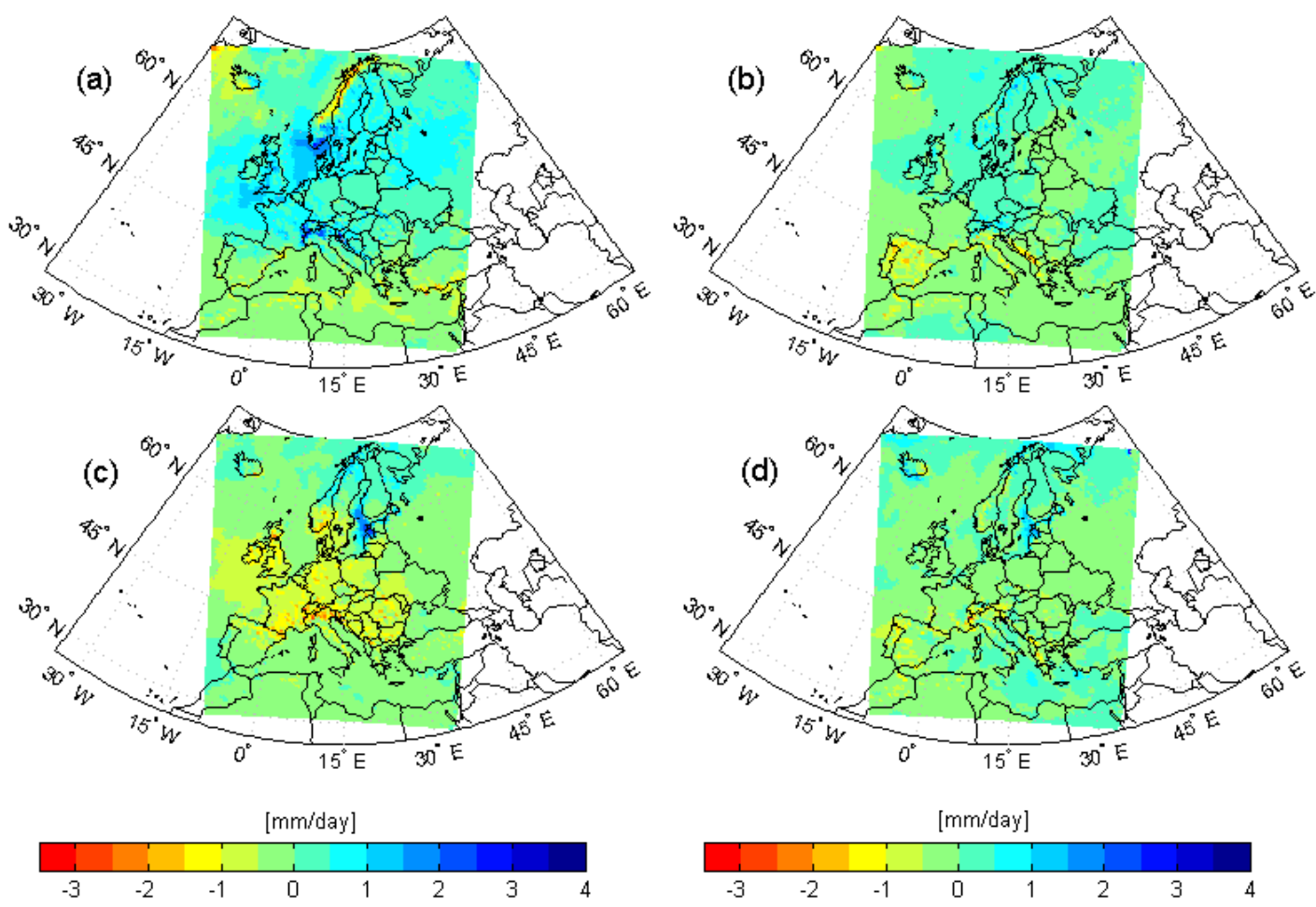

Fig. 4. Seasonal rainfall anomalies [mm day-1] for the entire HadRM3H integration domain (difference between the periods 2070-2100 and 1960-1990): (a) winter (December to February), (b) spring (March to May), (c) summer (June to August) and (d) autumn (September to November).
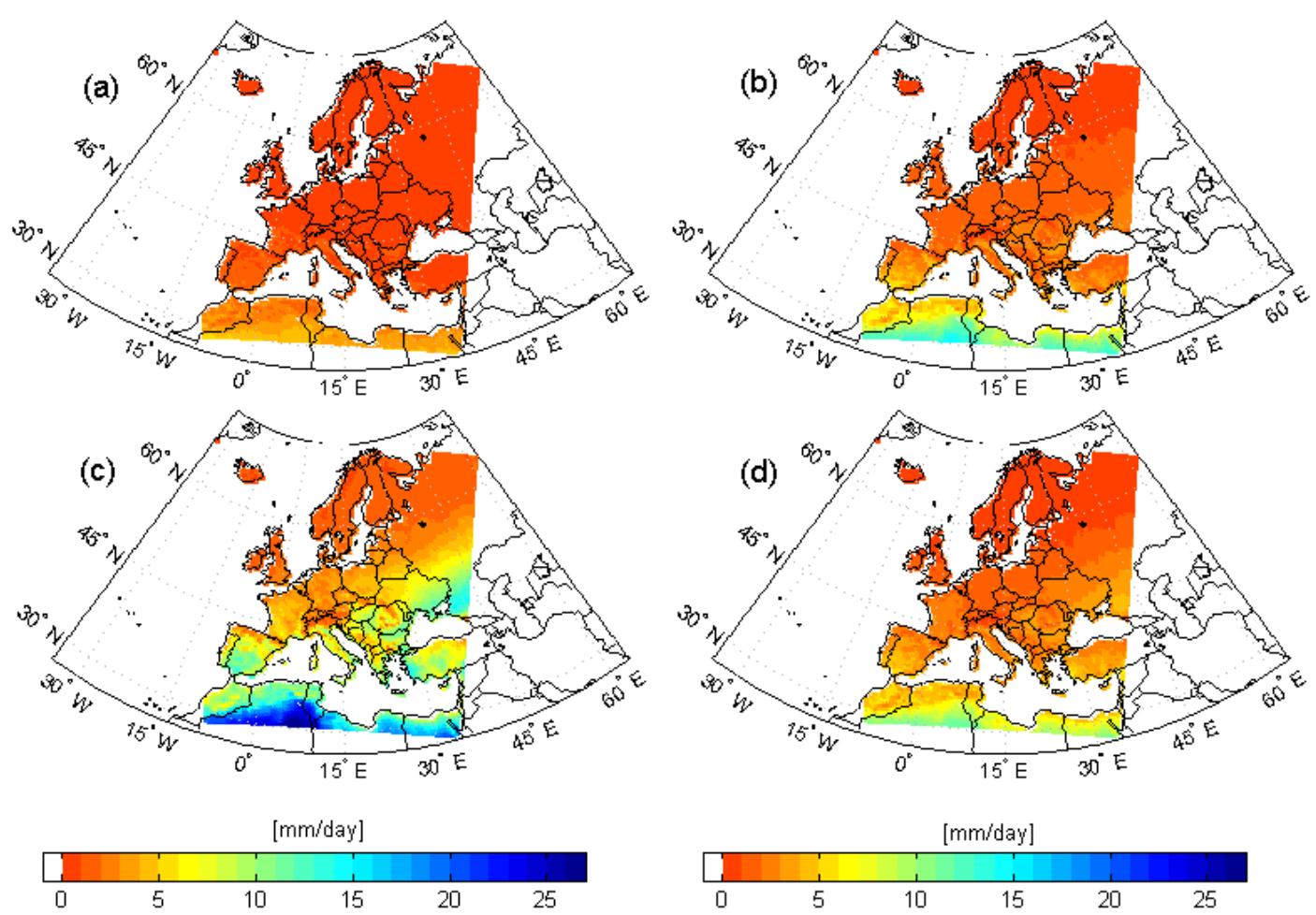

Fig. 5. Seasonal averages of FAO potential evapotranspiration [mm day-1] for the entire HadRM3H integration domain for the period 1960 1990; (a) winter (December to February), (b) spring (March to May), (c) summer (June to August) and (d) autumn (September to November). 

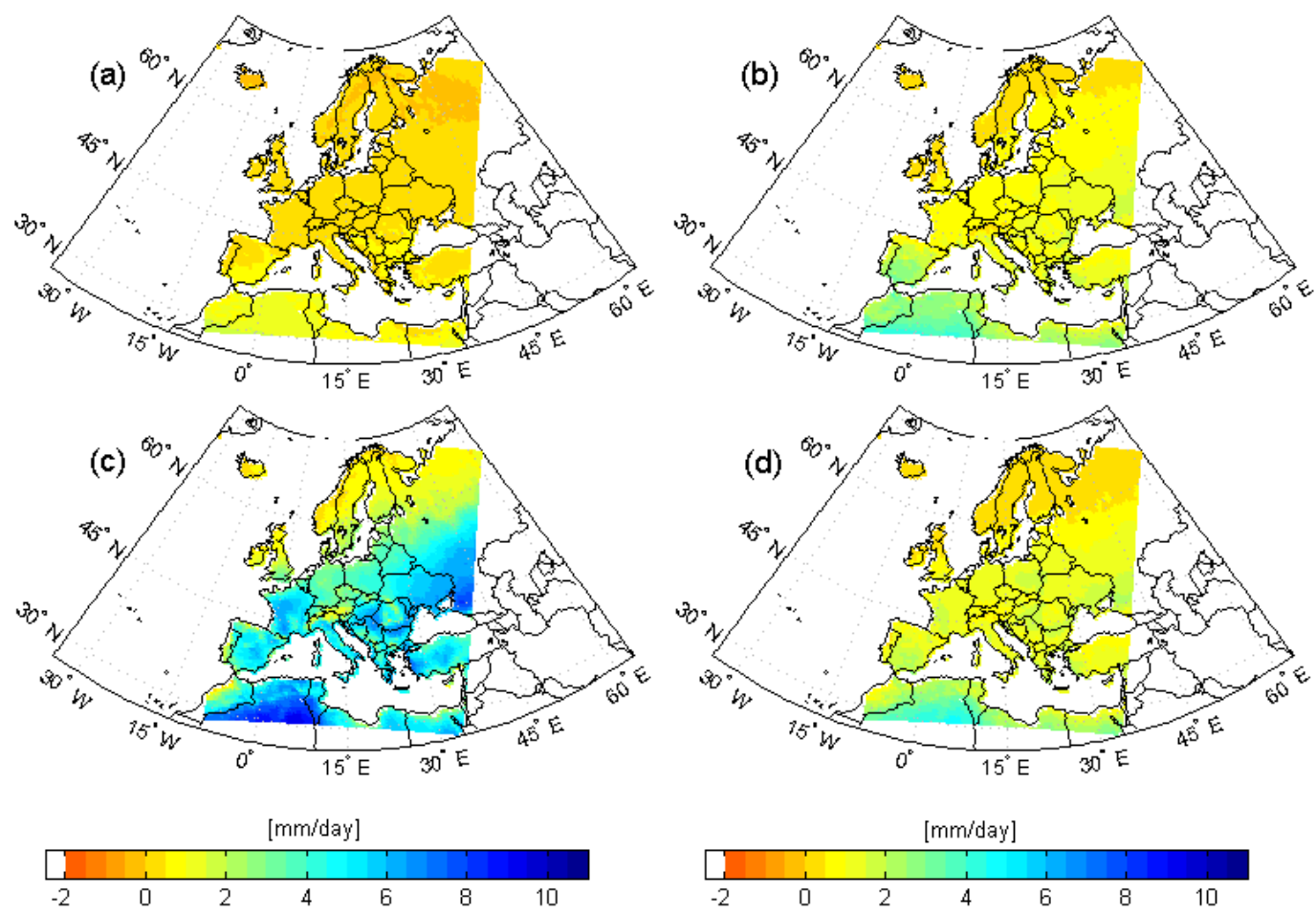

Fig. 6. Seasonal FAO potential evapotranspiration anomalies [mm day $\left.{ }^{-1}\right]$ for the entire HadRM3H integration domain (difference between the periods 2070-2100 and 1960-1990): (a) winter (December to February), (b) spring (March to May), (c) summer (June to August) and (d) autumn (September to November).

Europe in summer. In other seasons, the greatest increases are mainly in the northern parts of Russia and north-east Fennoscandia.

The largest projected changes in rainfall occur in winter (Fig. 4a) and summer (Fig. 4c). During winter, most of Europe, except for the central and northern parts of the Scandinavian mountain range, is projected to experience an increase in precipitation. The largest increase $(>1.5 \mathrm{~mm}$ day $^{-1}$ ) occurs over the North Sea, southern Norway and over much of the Alps. Projected changes are generally negative in summer, with most of western and central Europe showing a significant decrease in rainfall that becomes more extreme over the Alps and southern France $\left(>1.5 \mathrm{~mm} \mathrm{day}^{-1}\right.$ ) (Fig. $4 c)$. Increases in summer are generally confined to northern Scandinavia and in particular to the eastern part of the Baltic Sea. The pattern, in autumn, is similar, but less pronounced, to that of summer, Fig. 4d). The other transitional season, spring, is characterised by moderate decreases in rainfall over the Iberian Peninsula, parts of Italy and the Balkans (Fig. 4b). In short, projected changes in future rainfall have a clear seasonal structure, with the majority of Europe experiencing increases in winter and decreases in summer.

The FAO PET rate is generally $<5 \mathrm{~mm}^{\text {day }}{ }^{-1}$ over most of Europe (Fig. 5) in all seasons but summer when high rates $\left(>10 \mathrm{~mm} \mathrm{day}^{-1}\right)$ are found over parts of southern
Europe and the North African countries. The projected changes in PET rates for the perturbed climate are shown as anomaly patterns (Fig. 6). In summer, very large increases (4-8 $\mathrm{mm} \mathrm{day}^{-1}$ ) are projected for most of the European landmass, with the exception of the British Isles, Scandinavia and northern Russia (Fig. 6c). In the other seasons, for most of Europe, increases are more moderate, about $1 \mathrm{~mm} \mathrm{day}^{-1}$ in winter and 1-3 $\mathrm{mm} \mathrm{day}^{-1}$, in spring and autumn (Figs. $6 \mathrm{~b}$ and $6 \mathrm{~d}$ for spring and autumn respectively). In both spring and autumn, the increases are larger further south in the HadRM3H window.

\section{Validation of FAO PET}

The FAO PET for the control simulation was validated against PET observations for two of the five case study areas: NW England and the Rhine basin. The validation schemes in the respective case study areas were performed, respectively, by the partners from the University of Newcastle and from KNMI. As an alternative to the FAO PET, both groups decided to use an empirically-derived relationship to estimate PET for their specific case study regions. A summary of the validation exercise and the methodologies used to derive new PET estimations for NW England and the Rhine basin are given below. 


\section{NW ENGLAND}

A direct comparison of the FAO PET based on HadRM3H data and observations showed an under-estimation of the historic annual and monthly PET average for the control simulation (Fig. 7), particularly in summer. The standard practice for dealing with differences between modelled and observed climate variables has been to apply factors based on the ratio (or sometimes the difference, e.g. for temperature) of the observed values to the control simulation on a grid box basis (Durman et al., 2001). Here, a method of local scaling (Widmann et al., 2003) is used. This method simply multiplies the HadRM3H derived PET at each grid box by a monthly scale factor, taken from a fitting period (1960-1990) and applied to remove the long-term bias between the HadRM3H control scenario PET and the observed PET for the catchment. Thus, if $\operatorname{PET}_{\text {HadC }}(x, t)$ is the monthly-mean PET derived from HadRM $3 \mathrm{H}$ data at the grid box containing the location $x$ and at time $t$ in month $m$, the bias-corrected monthly-mean PET is:

$$
\operatorname{PET}_{B C}(x, t)=\operatorname{PET}_{\text {HadC }}(x, t) \frac{\left\langle P E T_{\text {obs }}\right\rangle_{m}}{\left\langle P E T_{\text {HadC }}\right\rangle_{m}}
$$

where $\langle\ldots\rangle_{m}$ is the monthly mean taken over the fitting period, 1960-1990.

The daily FAO PET (calculated from HadRM3H) data series were thus 'bias-corrected' by these monthly factors such that the HadRM3H control scenario monthly averages matched the observed monthly average PET over the 19601990 period. The future HadRM3H FAO PET time series were adjusted by the same monthly factors.

For daily temperatures over $12^{\circ} \mathrm{C}$, the adjusted daily PET values in the control run appear much higher than those calculated from the historical data (not shown). The spread in the HadRM3H FAO PET values was also much larger than those estimated from climatic observations. Historic daily values during 1961-1990 were in the range 0.4-3 mm, whereas values of up to $25 \mathrm{~mm}$ were produced for the HadRM3H control climate FAO PET, for essentially the same temperature range. In the future simulation, monthly PET estimates were as high as $370 \mathrm{~mm}$.

Due to the combination of low river flows and high temperatures in the case study area in summer, it is possible that the unrealistically high FAO PET values could have a large effect on the estimation of flow for the future scenarios (Fowler et al., 2007). To produce more plausible PET estimates, a simple regression-based approach was used to recalculate PET for the control and future scenarios. This method assumes that the historic 1961-1990 monthly relationship between PET and temperature (Walsh and Kilsby, 2007) can be extrapolated to a future climate. To compute the new PET values the following approach was used:

1. The coefficients of an empirical Blaney-Criddle equation (Blaney and Criddle, 1950) were derived using historic PET data by Walsh and Kilsby (2007). These were derived using a linear regression of temperature and PET data, (calculated using a Penman-Monteith type formulation) for observed climatic variables in a northwest England catchment in the Lake District region. The equation for PET is:

$$
P E T_{t}=p_{t}(\alpha T+\beta)
$$

\section{where}

$P E T_{t}=$ monthly PET estimated by Penman-Monteith formulation $\left[\mathrm{mm} \mathrm{month}{ }^{-1}\right]$

$p_{t}=$ mean daily percentage (for the month) of total annual daytime hours [\%]

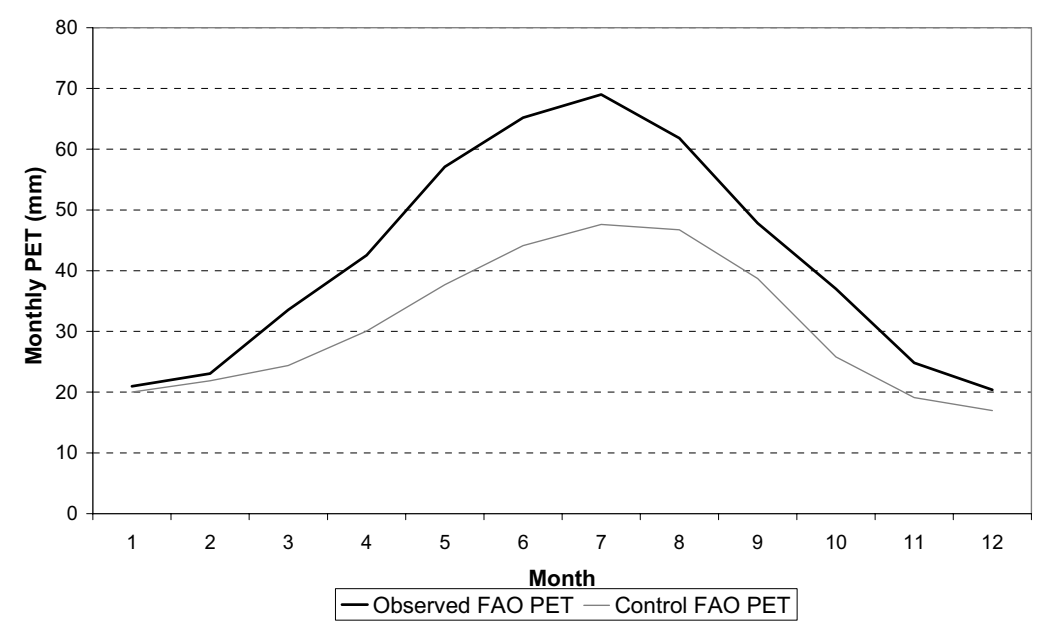

Fig. 7. Comparison of mean monthly PET calculated using the FAO Penman-Monteith method for observed and HadRM3H derived data. 
$\pm=$ empirically derived, $0.456\left[\mathrm{~mm}^{\circ} \mathrm{C}^{-1} \%{ }^{-1}\right]$

$\beta=$ empirically derived, $0.416\left[\mathrm{~mm} \mathrm{\%}^{-1}\right]$

$T=$ temperature $\left[{ }^{\circ} \mathrm{C}\right]$

The linearity in $T$ stems from the fact that PET is proportional to the Fahrenheit temperature in the original Blaney-Criddle formula. For more details on Eqn. (3), see Walsh and Kilsby (2007), particularly their Fig. 5.

2. Little difference was found between the historic PET Temperature relationship for different catchments in NW England (not shown) and so it is suggested that this relationship may be used successfully for any catchment in NW England.

3. The PET for the control and future simulation of HadRM3H was then computed using the above relationship but substituting daily temperatures from HadRM3H into the equation to estimate daily PET values.

The differences between monthly mean PET in the future scenario as predicted by the two methods can be seen in Fig. 8. The most striking differences occur in summer, although there are also substantial differences in spring and autumn. In winter, there is very little difference in future mean monthly PET between the two methods as daily average temperatures rarely reach $12^{\circ} \mathrm{C}$. Figure 9 shows the monthly percentage change in PET predicted for the future simulation (from HadRM $3 \mathrm{H}$ ) by the two methods. The FAO method predicts changes of up to $80 \%$ in average monthly PET during August and September and winter increases are predicted to be in the region of $20-30 \%$. The new PET method substantially lowers these estimates of change, with a more uniform change in PET throughout the year. This method predicts increases in PET of between 10 and 20\% in all months, with the months from July to September showing slightly larger increases than other months and is used in Fowler et al. (2007).

\section{THE RHINE BASIN}

For the Rhine basin, the FAO PET values, based on the results of the control simulation of $\operatorname{HadRM} 3 \mathrm{H}$, were reasonably close to the PET estimated from meteorological observations. The observed PET was based on reference evaporation for the period 1961-1990 as provided by different national meteorological services. The equations and input data for estimating PET are not known exactly. For the Swiss part of the basin, however, PET was derived from temperature using the Thornthwaite (1948) formula. After a relatively small bias correction (correcting for biases for each 10-day period of the year as described in Lenderink et al., 2007), the mean FAO PET (calculated from HadRM3H) values were very similar to calculations of PET from historical climatic observations. Figure 10 shows a scatter plot of PET against temperature for JJA based on monthly means, averaged over the Rhine area. The spread in the FAO PET computed from HadRM3H data was much larger than the spread in the observed PET. Observed monthly mean values were in the range 2-4 $\mathrm{mm} \mathrm{day}^{-1}$, whereas HadRM3H PET values were between 1-9 mm day ${ }^{1}$. For the future simulation, the FAO PET during summer increased from $3 \mathrm{~mm}$ day $^{-1}$ to nearly $7 \mathrm{~mm} \mathrm{day}^{-1}$ (after

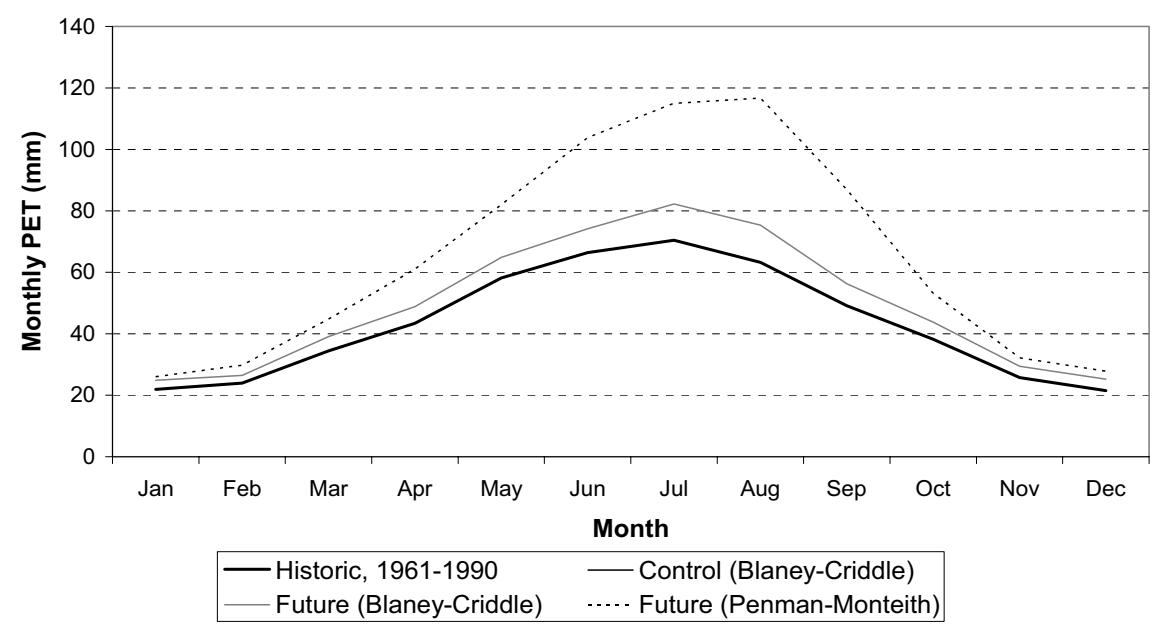

Fig. 8. Mean monthly PET for historic observations (1961-1990), control and future scenarios for the NW England case study area. BlaneyCriddle indicates scenarios where the observed relationship between PET and temperature has been used to construct PET series. Penman BC indicates scenarios where the FAO Penman-Monteith equation has been used to construct PET series with bias correction (BC). Note that "Historic, 1961-1990" and "Control Blaney-Criddle" are very similar, hence the former obscure the latter in the figure. 


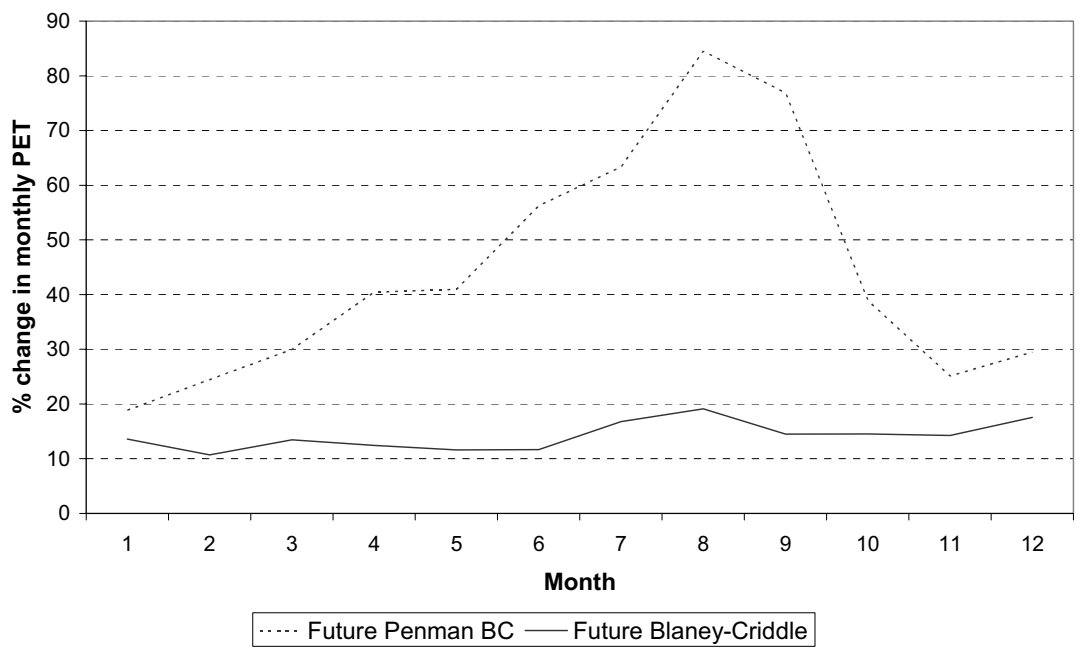

Fig. 9. Percentage monthly increases in PET for the period 2070-2100 in the NW England case study area compared to the period 1961-1990, predicted by the FAO Penman-Monteith equation with bias correction (Future Penman BC) and the PET estimated from the observed BlaneyCriddle relationship between PET and temperature (Future Blaney-Criddle).

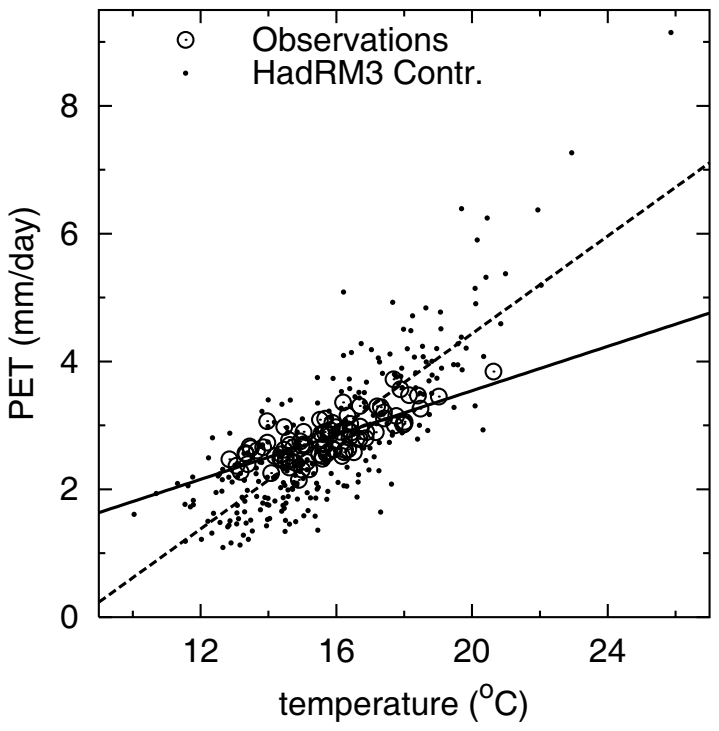

Fig. 10. Scatter plot of (basin-average) PET [mm day $\left.{ }^{-1}\right]$ against temperature $\left[{ }^{\circ} \mathrm{C}\right]$ for each month in summer (June to August). The solid line denotes a fit through the observations and the dashed line a fit through the model data.

correcting for the small bias in the control climate) and the extreme values increased to nearly $20 \mathrm{~mm} \mathrm{day}^{-1}$ (not shown).

The large values of bias-corrected FAO PET in dry summer months caused a substantial bias in the mean summer flows (Lenderink et al., 2007). As for the NW England case study (Fowler et al., 2007), an alternative scheme had to be employed to estimate a more plausible future PET. Since the hydrological model used for the Rhine area (Lenderink et al., 2007) uses a time step of 10 days,
PET was based on a regression of 10-day PET on temperature as follows:

1. A regression was computed for each calendar month and each grid box. Figure 11 shows a scatter plot of PET and temperature for a grid box in the centre of Germany for the month of August. In total 90 points are shown, corresponding to a 30 -year period with three 10 -day periods in each year. The regression was undertaken with anomalies, so with the mean PET and temperature (over these 90 points) subtracted. The regression coefficient (the slope of the fit) is denoted $\alpha_{\text {local }}$

2. The regression coefficients were averaged over the Rhine basin, giving $\alpha_{\text {area }}$. This spatial averaging was performed to filter out noise.

3. Due to the spatial averaging all spatial information is lost. This leads to problems over mountainous areas where the mean values of PET are low, causing negative values of the re-computed PET when the relatively large area mean $\alpha_{\text {area }}$ is used. Therefore, a local correction was applied based on the local 30-year average PET for the month of interest, $\overline{P E T}_{\text {local }}$, divided by the 30 year area-average PET for that month, $\overline{P E T}_{\text {area }}$.

4. The evaporation anomaly $\triangle P E T(t)$, with respect to the local mean for the month of interest, was computed from: 


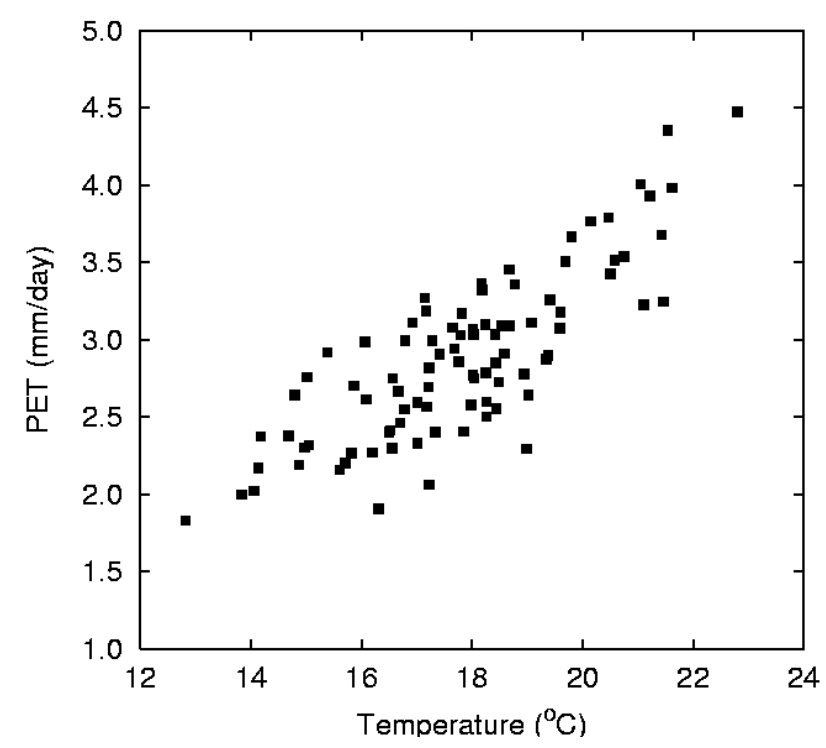

Fig. 11. Scatter plot of PET $\left[\mathrm{mm}\right.$ day $\left.{ }^{-1}\right]$ against temperature $\left[{ }^{\circ} \mathrm{C}\right]$ for each 10-day period in August for one location in the centre of Germany.

$$
\Delta \operatorname{PET}(t)=\alpha_{\text {area }} \frac{\overline{P E T}_{\text {local }}}{\overline{P E T}_{\text {area }}} \Delta T(t), \quad t=1, \ldots, 36 J
$$

with $\Delta T(t)$ the temperature anomaly (again compared to the local mean for the month of interest), $J$ the number of years and $36 J$ the number of 10 -day periods in the simulation.

The values from the Thornthwaite formula for the Swiss part of the basin could not be used for the estimation of the spatial average relationship in step 2 . They were, however, included in the area-averages $\overline{P E T}_{\text {area }}$.

The relative domain-averaged changes in PET per degree (basin mean change divided by the basin mean PET) are shown in Fig. 12. For the summer, the increase in PET is nearly $8 \%$ per degree temperature change. This result agrees well with a $10 \%$ increase per degree found by Brandsma (1995) from a regression of open water evaporation (based on the Penman equation) on temperature for a station in the Netherlands. Apart from a regression on temperature, Brandsma (1995) also recalculated the evaporation by changing the temperature but keeping the other input variables of the Penman equation (relative humidity, sunshine duration and wind speed) unchanged. This resulted in a much smaller increase (3-4\%) of evaporation with increasing temperature in summer. It is not clear what the most appropriate value is for the change in PET in a warmer climate. Therefore, different scenarios for PET were developed from Eqn. (4). The temperature anomalies for the future climate can be split into a contribution of the mean temperature change between future and control climate,

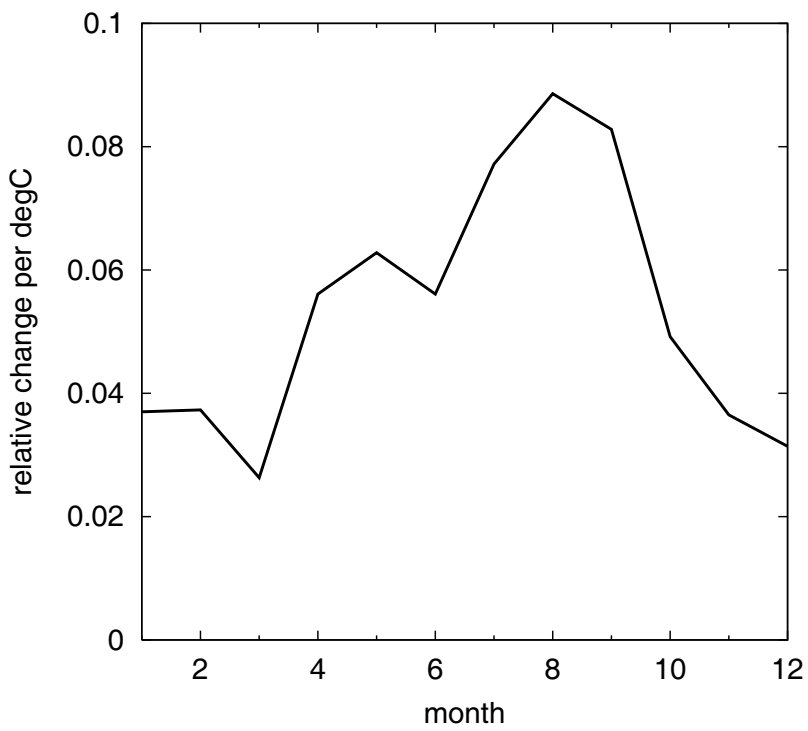

Fig. 12. The domain-averaged relative change in PET per degree (basin-average change divided by basin-average PET).

$\bar{T}_{\text {fut }}-\bar{T}_{\text {cont }}$ (as a function of time of the year and location), and a remaining part accounting for variations in the weather:

$$
\Delta T_{\text {fut }}(t)=T_{\text {fut }}(t)-\bar{T}_{\text {cont }}=\left[\bar{T}_{\text {fut }}-\bar{T}_{\text {cont }}\right]+\left[T_{\text {fut }}(t)-\bar{T}_{\text {fut }}\right],
$$

$$
t=1, \ldots, 36 J
$$

where $T_{\text {fut }}(t)$ are the simulated 10-day temperatures for the future climate.

Three different scenarios for the future PET were constructed by multiplying the mean temperature-change related contribution by a factor $\beta$ :

- $\beta=0.0$ (low scenario). This scenario represents a lower limit giving no change in the mean PET.

- $\beta=0.5$ (middle scenario), giving an increase of about $25 \%$ in PET in summer, or nearly $4 \%$ per ${ }^{\circ} \mathrm{C}$, which is very similar to the increase in the scenarios used by Shabalova et al. (2003) in an earlier application of regional climate model output to the Rhine basin.

- $\beta=1.0$ (high scenario), representing an extrapolation of the present PET temperature relation to the future climate.

It should be noted that the change in PET for NW England from the empirical Blaney-Criddle equation in summer is comparable to that in the $\beta=0.5$ scenario and not the $\beta=1.0$ scenario. Apart from climatological differences between NW 
England and the Rhine basin and the use of different methods to estimate PET from observations, the relatively low sensitivity of the empirical Blaney-Criddle equation might be due to the assumption of constant regression coefficients $\alpha$ and $\beta$ over the year.

\section{Discussion and conclusions}

The future simulations of HadRM3H temperature and rainfall, following the $\mathrm{A} 2$ emission scenario, suggest that the majority of Europe will experience future warming in all seasons, (Fig. 2), with heavier precipitation in winter in much of western Europe (except for central and northern parts of the Scandinavian mountains) (Fig. 4a) and drier summers in most parts of western and central Europe (except for the north-west and the eastern part of the Baltic Sea) (Fig. 4c). Particularly large temperature anomalies $\left(>6^{\circ} \mathrm{C}\right)$ are projected for north-east Europe in winter (Fig. 2a) and for southern Europe, Asia Minor and parts of Russia in summer (Fig. 2c).

The simulation of summer temperature in south-eastern Europe and Asia Minor is, however, known to be associated with a warm bias, seen not only in HadRM3H (Jones et al., 2001b) but also in many other RCMs (Hagemann et al., 2001). Jones et al. (2001b) describe this problem in some detail. An unfortunate side effect of increasing the resolution in HadAM3H is the worsening of an already existing warm bias in summer temperatures over large parts of Europe, with the increased resolution upsetting a balance of errors operating in HadAM3, the atmospheric component of HadCM3 (Jones et al., 2001b). More specifically, the increased resolution leads to an intensification of the hydrological cycle (stronger surface winds and evaporation, stronger vertical motion, reductions in atmospheric relative humidity and more heavy precipitation events) (Jones et al., 2001b). The intensified hydrological cycle, however, also leads to lower cloud cover, which is already low in HadAM3 but to some degree balanced by other biases. With lower cloud cover follows increased insolation, which results in increased surface heating. To counteract the problem, some modifications were made to the cloud physics in the model and to the coupling between the soil and the land surface in HadAM3H to improve the simulation of the summer temperatures whilst keeping the high resolution (Jones et al., 2001b). Comparison with HadAM3 showed that the modifications reduced the warm bias in large parts of Europe. However, the bias still remains in south-east Europe and Asia Minor (Jones et al., 2001b). It is not clear, therefore, whether the large warming in south-east Europe and Asia Minor in summer can be considered as 'real' or enhanced by limitations in representing the hydrodynamics by the RCM.

Of particular interest in this study was the estimation of PET, which is necessary for hydrological modelling in the case study regions. This study shows how outputs from HadRM3H can be used in combination with a variant of the Penman-Monteith method developed by the FAO (Allen et al., 1994) (Eqn. 1), to estimate PET for the HadRM3H window. However, comparisons of the control simulation FAO PET and observations for NW England and the Rhine basin reveal biases that cannot be corrected by a simple multiplicative adjustment. Furthermore, the future FAO PET values are clearly not physically realistic and cannot, therefore, be used for hydrological simulations in these regions. Instead, PET is estimated directly from temperature using empirical relationships based on observed meteorological data from each specific location.

Given that the FAO method has previously been preferred to several other methods in a comparative test to estimate PET for European environments (Jones et al., 2001a), it was surprising to find such poor results, primarily in summer, using the HadRM $3 \mathrm{H}$ data. The intensification of the hydrological cycle due to the higher resolution in the regional modelling scheme, as described by Jones et al. (2001b), could, however, be the underlying cause for these extreme PET values. An unrealistically large hydrological feedback in the HadRM3H-generated climate would cause dry conditions leading to low cloud amounts, high surface radiation, high surface temperatures and consequently high vapour pressure deficits near the surface. If this were the case, large changes in these variables would be expected between the control and the future simulation. Therefore, anomaly maps of the future compared with the control simulation were created for those variables that were expected to have the largest influence on the magnitude of the FAO PET: relative humidity [\%], temperature $\left[{ }^{\circ} \mathrm{C}\right]$, total cloud from long wave radiation [fraction] (all three are HadRM3H variables) and vapour pressure deficit $[\mathrm{kPa}]$ (the difference between the saturation vapour pressure and the actual vapour pressure, calculated in the FAO method) (Fig. 13c). The graphs are based on data from only one of the three HadRM3H ensemble members (A2a), as the same trend would be expected in all HadRM $3 \mathrm{H}$ model experiments. Furthermore, only summer data are used as the impact of the hydrological feedback should be greatest in the warm season.

The maps show that most regions with large predicted increases in summer temperatures (Fig. 13a) also show large decreases (10 to $40 \%)$ in relative humidity predicted by HadRM3H (Fig. 13b), which, in combination with the high temperatures, produce large increases in the vapour pressure deficit (Fig. 13c). A region stretching from southern France, 

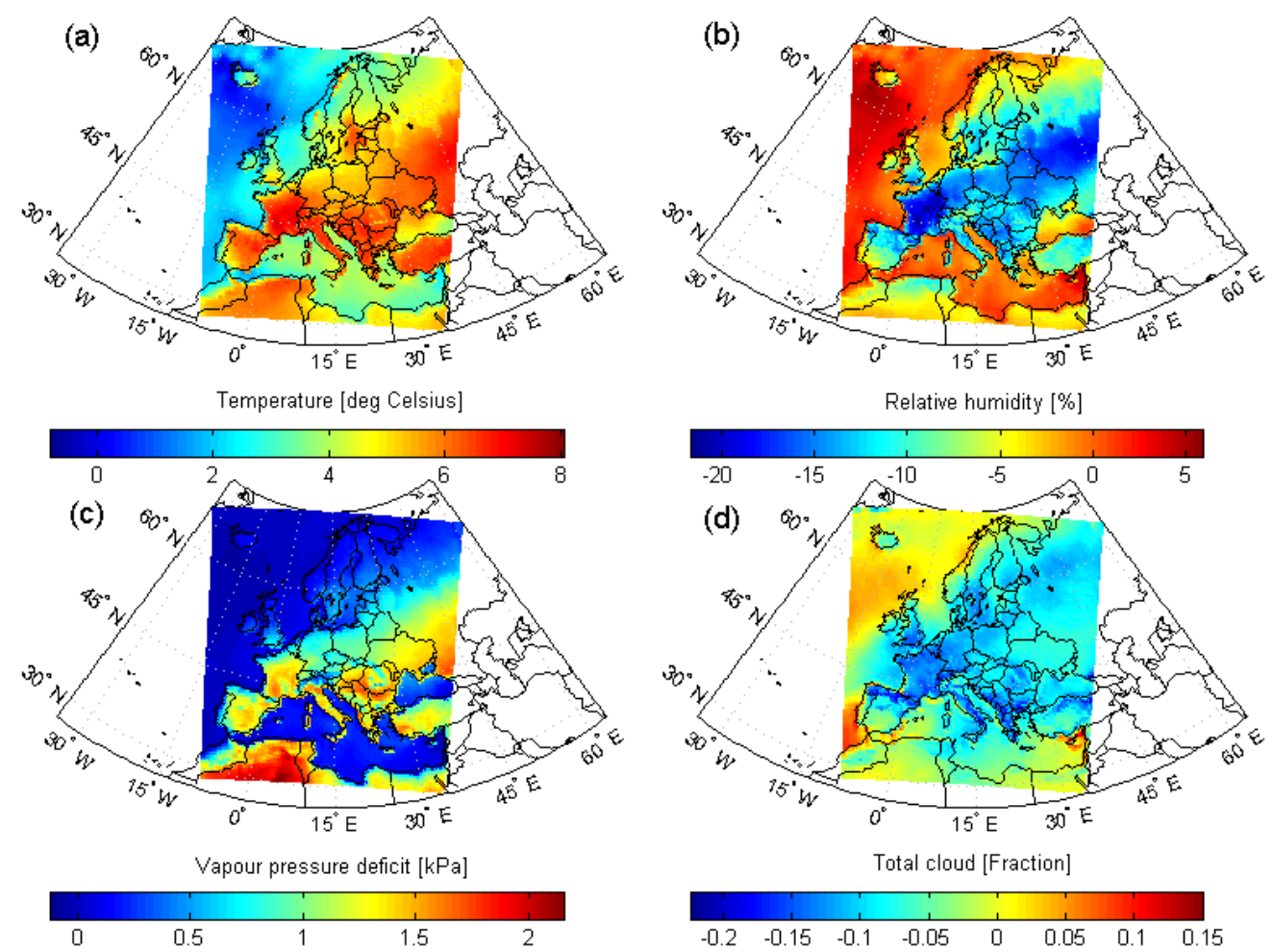

Fig. 13. Summer anomalies between HadRM3H control and future simulation (following the A2 emissions scenario) for (a) temperature [ $\left.{ }^{\circ} \mathrm{C}\right]$, (b) relative humidity [\%], (c) vapour pressure deficit [kPa] and (d) total cloud [Fraction].

crossing central Europe towards Russia, is predicted to have an overall increase in vapour pressure deficit of around 1 to $2 \mathrm{kPa}$ (Fig. 13c). Even larger increases are predicted in some isolated areas of France, the Netherlands, Germany and Russia. In addition to the changes in vapour pressure, PET is further enhanced by increases in the net radiation term. The reduced cloud coverage in the future climate (Fig. 13d) leads to an increase in the net shortwave radiation term and, hence, an overall increase in the total net radiation term. Considering all maps, however, the similarity in the spatial patterns and magnitude of change between the PET (Fig. 6c) and vapour pressure deficit (Fig. 13c) indicated clearly that the latter was the main cause of the high evapotranspiration rates when using the FAO method in combination with the direct output of HadRM $3 \mathrm{H}$. Furthermore, the high vapour pressure deficits are most likely related to soil drying, leading to low evapotranspiration rates, low relative humidity and high surface temperatures. It is probable that the lack of low level clouds causes excessive insolation at the surface, leading to the dry bias and warm bias of the model.

It is clear that the representation of the hydrological cycle can be improved further in climate models. In addition to cloud parameterisations, which have been subject to large improvements in different generations of Hadley Centre models, there is also room for improvement in the description of soil processes and the interactions between the atmosphere and the land surface. As such, the terrestrial water storage reservoir is a critical parameter in regional models, determining to a large extent the sensitivity of the model to soil drying. Van den Hurk et al. (2005) show that in an ensemble of regional climate models the storage capacity is under-estimated and attribute part of the large temperature response in these models to this property. Some recent publications also address land-atmosphere feedback using observations (Koster et al., 2003; Pal and Eltahir, 2002). Koster et al. (2003) found an agreement between spatial structures in precipitation variance and autocorrelation fields between a 50-year observational dataset and those produced by an atmospheric general circulation model, which disappeared if the land-atmosphere feedback was artificially disabled in the model. Furthermore, Pal and Eltahir (2002) showed that, depending on the location, soil moisture anomalies over relatively small regions could alter rainfall significantly, both locally and in surrounding regions.

Some modifications that could improve the hydrological cycle in the regional modelling scheme have been included 
by the Hadley Centre in their new version of the RCM, HadRM3P (Richard Jones, pers. comm., in Moberg and Jones, 2004). Differences between HadRM3P and HadRM3H are, however, very small for temperature and precipitation; this suggests that potential PET biases would still be large if a Penman-type formula were used.

Finally, for SWURVE, a simple temperature-based computation of PET had to be used, apparently because the hydrological cycle in HadRM3H is not sufficiently realistic to allow the use of the more physically-based FAO PET. Results obtained in the PRUDENCE project (with an ensemble of RCMs all driven by the same HadAM3H boundaries) indicate that the hydrological cycle is, generally, a weak point in regional models (e.g. Van den Hurk et al. 2005; Hagemann et al., 2004). Therefore, the application of these models for downstream hydrological impact modelling will benefit from an improvement in the representation of the hydrological cycle.

\section{Acknowledgments}

The authors would like to thank David Viner at the Climatic Research Unit of the University of East Anglia, UK, for aiding the access to HadRM3H data, which were supplied by the Climate Impacts LINK project (DEFRA Contract EPG 1/1/154) on behalf of the Hadley Centre and UK Met Office. The meteorological data for the Rhine basin were made available by the following institutions: Deutscher Wetterdienst, Service de la météorologie et de l'hydrologie de Luxembourg, Météo France and Swiss Meteorological Institute, via the International Commission for the Hydrology of the Rhine basin (CHR/KHR). This work is part of the SWURVE (Sustainable Water: Uncertainty, Risk and Vulnerability Estimation in Europe) project, partly funded under the EU Environment and Sustainable Development programme, grant number EVK1-200000075.

\section{References}

Allen, M.R. and Ingram, W.J., 2002. Constraints on future changes in climate and the hydrologic cycle. Nature, 419, 224-232.

Allen, R.G., Smith, M., Pereira, L.S. and Perrier, A., 1994. An update for the calculation of reference evapotranspiration. ICID Bulletin, 43, 35-92.

Anderson, M.L., Kavvas, M.L. and Mierzwa, M.D., 2001. Probabilistic/ensemble forecasting: a case study using hydrologic response distributions associated with El Nino/ Southern Oscillation (ENSO). J. Hydrol., 249, 134-147.

Blaney, H.F. and Criddle, W.D., 1950. Determining water requirements in irrigated areas from climatological and irrigation data, USDA, Soil Conservation Service, TP-96.

Brandsma, T., 1995. Hydrological impact of climate change, a sensitivity study for the Netherlands. PhD thesis, Delft University of Technology.
Cox, P., Betts, R.A., Bunton, C., Essery, R., Rowntree, P.R.R. and Smith, J., 1999. The impact of new land surface physics on the GCM simulation of climate and climate sensitivity. Clim. Dynam., 15,183-203.

Durman, C.F., Gregory, J.M., Hassell, D.C., Jones, R.G., and Murphy, J.M., 2001. A comparison of extreme European daily precipitation simulated by a global and a egional climate model for present and future climates. Quart. J. Roy. Meteorol. Soc., 127, 1005-1015.

Ekström, M., Hingray, B., Mezghani, A. and Jones, P.D., 2007. Regional climate model data used within the SWURVE project 2: addressing uncertainty in regional climate model data for five European case study areas. Hydrol. Earth Syst. Sci., 11, 1085-1096.

Fowler, H.J., Kilsby, C.G. and Stunell, J. 2007. Modelling the impacts of projected future climate change on water resources in northwest England. Hydrol. Earth Syst. Sci., 11, 1115-1126.

Giorgi, F. and Mearns, L.O., 2002. Calculation of average, uncertainty range, and reliability of regional climate changes from AOGCM simulations via the "Reliability Ensemble Averaging" (REA) method. J. Climate, 15, 1141-1158.

Gordon, C., Cooper, C., Senior, C.A, Banks, H.T., Gregory, J.M., Johns, T.C., Mitchell, J.F.B. and Wood, R.A., 2000. The simulation of SST, sea ice extents and ocean heat transports in a version of the Hadley Centre coupled model without flux adjustments. Clim. Dynam., 16, 147-168.

Grotch, S.L. and MacCracken, M.C., 1991. The use of general circulation models to predict regional climate change. J. Climate, 4, 286-303.

Hagemann, S., Botzet, M. and Machenhauer, B., 2001. The summer drying problem over south-eastern Europe: sensitivity of the limited area model HIRHAM4 to improvements in physical parameterization and resolution. Phys. Chem. Earth (B), 26, 391-396.

Hagemann, S., Machenhauer, B., Christensen, O.B., Déqué, M., Jacob, D., Jones, R.G., and Vidale, P.L., 2004. Evaluation of water and energy budgets in regional climate models applied over Europe. Clim. Dynam., 23, 547-567.

Hulme, M., Jenkins, G.J., Lu, X., Turnpenny, J.R., Mitchell, T.D., Jones, R.G., Lowe, J., Murphy, J.M., Hassell, D., Boorman, P., McDonald, R. and Hill, S., 2002. Climate Change Scenarios for the United Kingdom: The UKCIP02 Scientific Report, Tyndall Centre for Climate Change Research, School of Environmental Sciences, University of East Anglia, Norwich, UK, $112 \mathrm{pp}$.

IPCC, 2000. Technical Summary. In: Special Report on Emissions Scenarios, N. Nakicenovic and B. Swart (Eds). Cambridge Univ. Press, Cambridge, UK.

Jenkins, G. and Lowe, J., 2003. Handling uncertainties in the UKCIPO2 scenarios of climate change. Hadley Centre Technical note 44.

Johns, T.C., Carnell, R.E., Crossley, J.F., Gregory, J.M., Mitchell, J.F.B., Senior, C.A., Tett, S.F.B. and Wood, R.A., 1997. The second Hadley Centre Coupled Ocean-Atmosphere GCM: model description, spinup, and validation. Clim. Dynam., 13, 103-134.

Johns, T.C., Gregory, J.M., Ingram, W.J., Johnson, C.E., Jones, A., Lowe, J.A., Mitchell, J.F.B., Roberts, D.L., Sexton, D.M.H., Stevenson, D.S., Tett, S.F.B. and Woodage, M.J., 2003. Anthropogenic climate change for 1860 to 2100 simulated with the HadCM3 model under updated emissions scenarios. Clim. Dynam., 20, 583-612.

Jones, R.N., 2000a. Analysing the risk of climate change using an irrigation demand model. Climate Res., 14, 89-100.

Jones, R.N., 2000b. Managing uncertainty in climate change projections - issues for impact assessments. Climatic Change, 45, 403-419. 
Jones, P.D., Reid, P. and Conway, D., 2001a. Data sets and scenarios. In: Water Resources: INfluence of CLimate change in Europe, C. Kilsby (Ed.). Final Report WRINCLE, EU Environment and Climate Research Programme ENV4-CT970452, Univ. of Newcastle, Newcastle upon Tyne, UK. 4-18.

Jones, R., Murphy, J., Hassell, D. and Taylor, R., 2001b. Ensemble mean changes in a simulation of the European climate of 2071 2100 using the new Hadley Centre regional modelling system HadAM3H/HadRM3H. Hadley Centre Report, Met Office Bracknell, UK.

Kilsby, C., 2007. Sustainable water: uncertainty risk and vulnerability in Europe. Hydrol. Earth Syst. Sci., 11, 1175-1189.

Koster, R.D., Suarez, M.J., Higgins, R.W. and Van den Dool, H.M., 2003. Observational evidence that soil moisture variations affect precipitation. Geophys. Res. Lett., 30, 1241, doi:10.1029/ 2002GL016571.

Lenderink, G., Buishand, T.A. and van Deursen, W.P.A., 2007. Estimates of future discharges of the river Rhine using two climate scenario methodologies: direct versus delta approach. Hydrol. Earth Syst. Sci., 11, 1145-1159.

Levitus, S. and Boyer, T. P., 1994. World Ocean Atlas 1994, Volume 4: Temperature. NOAA/NESDIS E/OC21, US Department of Commerce, Washington, DC, $117 \mathrm{pp}$.

Levitus, S., Burgett, R. and Boyer, T. P., 1995. World Ocean Atlas 1994, Volume 3: Salinity. NOAA/NESDIS E/OC21, US Department of Commerce, Washington DC, USA. 99pp.

Moberg, A. and Jones, P.D., 2004. Regional climate model simulations of daily maximum and minimum near-surface temperatures across Europe compare with observed station data 1961-1990. Clim. Dynam., 23, 695-715.

Pal, J.S. and Eltahir, E.A.B., 2002. Teleconnections of soil moisture and rainfall during the 1993 midwest summer flood. Geophys. Res. Lett., 29, 1865, doi:10.1029/2002GL014815.

Pope, V.D., Gallani, M.L., Rowntree, P.R. and Stratton, R.A., 2000. The impact of new physical parameterizations in the Hadley Centre climate model: HadAM3. Clim. Dynam., 16, 123-146.

Räisänen, J., 2000. CO -induced climate change in northern Europe: comparison of 12 CMIP2 experiments. SMHI Reports Meteorology Climatology, 87.
Räisänen, J., Hansson, U., Ullerstig, A., Döscher, R., Graham, L.P., Jones, C., Meier, M., Samuelsson, P. and Willén, U., 2004. European climate in the late twenty-first century: regional simulations with two driving global models and two forcing scenarios. Clim. Dynam., 22, 13-31.

Shabalova, M.V., van Deursen, W.P.A. and Buishand, T.A., 2003. Assessing future discharge of the river Rhine using regional climate model integrations and a hydrological model. Climate Res., 23, 233-246.

Thornthwaite, C.W., 1948. An approach towards a rational classification of climate. Geogr. Rev., 38, 55-94.

Van den Hurk, B, Hirschi, M., Schär, C., Lenderink, G., van Meijgaard, E., van Ulden, A., Rockel, B., Hagemann, S., Graham, P., Kjellström, E., and Jones, R., 2005. Soil control on runoff response to climate change in regional climate model simulations. J. Climate, 18, 3536-3551.

Viner, D. and Hulme, M., 1997. The climate impacts LINK project: results of the Hadley Centre's climate change experiments for climate change impacts assessments. UK DETR Report, Climatic Research Unit, University of East Anglia, Norwich, UK.

Walsh, C. and Kilsby, C., 2007. Implications of climate change on flow regime affecting Atlantic salmon. Hydrol. Earth Syst. Sci., 11, 1127-1143.

Widmann, M., Bretherton, C.S. and Salathé, E.P., 2003. Statistical precipitation downscaling over the northwestern United States using numerically simulated precipitation as a predictor. $J$. Climate, 16, 799-816.

Wigley, T.M.L. and Raper, S.C.B., 2001. Interpretation of high projections for global-mean warming. Science, 293, 451-454.

Wood, R.A., Keen, A.B., Mitchell, J.F.B. and Gregory, J.M., 1999. Changing spatial structure of the thermohaline circulation in response to atmospheric $\mathrm{CO}_{2}$ forcing in a climate model. Nature, 399, 572-575.

Zorita, E. and von Storch, H., 1999. The analog method as a simple statistical downscaling technique: Comparison with more complicated methods. J. Climate, 12, 2474-2489. 